\title{
Lexis
}

Journal in English Lexicology

$14 \mid 2019$

Blending in English

\section{To blend so as to brand: a study of trademarks and brand names}

Jelena Danilović Jeremić and Jelena Josijević

\section{OpenEdition}

9 Journals

\section{Electronic version}

URL: http://journals.openedition.org/lexis/3732

DOI: $10.4000 /$ lexis.3732

ISSN: 1951-6215

\section{Publisher}

Université Jean Moulin - Lyon 3

\section{Electronic reference}

Jelena Danilović Jeremić and Jelena Josijević, «To blend so as to brand: a study of trademarks and brand names », Lexis [Online], 14 | 2019, Online since 16 December 2019, connection on 10 December 2020. URL : http://journals.openedition.org/lexis/3732 ; DOI : https://doi.org/10.4000/lexis.3732

This text was automatically generated on 10 December 2020.

\section{(c) (i) (9)}

Lexis is licensed under a Creative Commons Attribution-NonCommercial-NoDerivatives 4.0 International License. 


\title{
To blend so as to brand: a study of trademarks and brand names
}

\author{
Jelena Danilović Jeremić and Jelena Josijević
}

The authors gratefully acknowledge support from the Ministry of Education, Science and Technological Development of the Republic of Serbia (project grant 178014).

\author{
[...] brand names are fascinating, both in form \\ and in meaning, because they are more \\ consciously created than any other words. [Ingrid \\ Piller 2005]
}

\section{Introduction}

1 We live in an era of global consumerism, with new products or services being launched on a daily basis. To make an entry into the highly competitive market, consumer products need, first and foremost, to be named in line with the two governing principles: language economy and creativity. As Room [1994:2] aptly put it, brand names both designate and advertise; they are created to convey information, carry desirable connotations and generate favorable perceptions. An attractive brand name can contribute to the recognition and appreciation of a particular product, providing it with a competitive advantage. Hence, brand names represent potent marketing devices, in terms of their ability to motivate customers and the quality of legal protection they are entitled to [Blackett 1998:14]. While the packaging, price, advertising campaign, promotion, and even the product itself are subject to change, brand names are not. The familiarity and consistency of usage can result in brand names becoming widely accepted by the general public, so much so that successful linguistic creations become conventionalized (e.g. popsicle, granola, frisbee) or are used metaphorically (e.g. to hoover something up).

2 Although arbitrary collections of letters are occasionally used when new artifacts are named (e.g. Tylenol), advertising experts prefer to coin new words from old ones [Stockwell \& Minkova 2001: 5], e.g. Biofreeze, Re-dew, Paingone, Yum Yum. Derivation and 
compounding, as major word-building processes, seem to be most frequently employed in brand naming practices [Praninskas 1968: 29; Panić 2004: 287]. Blending is quite productive too, as evidenced by trade names which have developed generic usage (e.g. breathalyzer, astroturf, laundromat, vegeburger) as well as recent coinages (e.g. Snapscara, MiracOILous, or Collagenesis, to name but a few from the semantic field of cosmetics). The evident popularity of blends in brand names can be attributed to the fact that they represent not only highly creative but also playful linguistic tools that emerge as a synthesis of clipping and compounding. The combination of these two morphological mechanisms enables the formation of a unique lexical unit whose semantics is linked to both source words. As Rivkin and Sutherland [2004: 51] put it,

Coined names, even those that seem completely new, rely on the hearers' unconscious understanding of the bits and pieces of language, and their ability to transfer those new meanings to the name. Smart names choose just enough of these bits to create good feeling, leaving room for people to associate the specifics of their product with the name.

The loss of lexical material in blends coupled with the puzzle of novelty call for greater processing effort, which is why consumers, having figured out the intended meaning of the referent, might experience satisfaction and develop a positive attitude toward the product [Lehrer 2003: 52].

Even though blending is generally thought to have increased in popularity since the middle of the $20^{\text {th }}$ century, due to the growing influence of the mass media and advertising [Adams 1973: 149; Cannon 1986: 737], it can be traced to product names earlier than that. According to Gitlin and Ellis [2011: 40], Cerealine and Directoyu were introduced as corn flake clones c. 1910. In addition, Pound [1914:21] mentions Everlastic, Locomobile and Sealpackerchief in her classification of blends from roughly the same period. In the 1930s, Berrey [1939] made a record of Feminalls, Bisquick, Tweeduroy and Playjamas. We can therefore state that blending has, for over a century now, fulfilled one of the basic marketing needs - that of naming a new product. Bearing in mind the sheer number of articles of merchandise that were introduced in the $20^{\text {th }}$ century, we would expect an in-depth examination to have been performed on blends in brand names, but this does not seem to be the case. Numerous linguists make a passing reference to the productivity of blending in trade names [Marchand 1969; Hladky 1971; Adams 1973; Ungerer 1991; Piller 1995; Cannon 2000; Lehrer 2007; Lieber 2009]. Few have collected a sizeable corpus of such blends though [Praninskas 1968; Bryant 1974; Thurner 1993] and none have, to our knowledge, undertaken their detailed analysis. The aforementioned collections of lexical items can nowadays, admittedly, be considered outdated. Still, they provide valuable insight into one of the most intriguing linguistic phenomena and its distinguishing features.

Inspired by the comparative scarcity of pertinent studies on blending [Bauer, Lieber \& Plag 2015: 462], we intend to enrich the existing body of literature with a view on blends as brand names by scrutinizing the Thurner corpus [1993], identifying the underlying motivations (phonological, graphological, stylistic) of the target blends and drawing comparisons with other relevant 'blend-a-sets' (e.g. Praninskas [1968]; Bryant [1974]). But first, in the next two sections, let us briefly present the linguistic sources of brand names and trademarks, and examine the role of blending in brand naming. 


\section{The creation of brand names: Key considerations}

6 The terms brand name, business name, corporate name, product name, proprietary name, registered name, service name and trade name are often considered synonymous [Piller 1999: 325]. The two most widely used, brand name and trade name or trademark, are commonly used in their generic sense, to refer to any name that distinguishes an article sold or a service produced by a manufacturer from those of his competitors (Merriam-Webster online). As Lippincott and Margulies [1961] remarked almost half a century ago, tens of thousands of names are registered by the US and Trademark office each year, which renders finding new names for products increasingly difficult. This claim appears to be even more true in an era characterized by the rise of modern technology, globalization and mass consumerism. In this multi-billion dollar industry, massive commercial efforts are nowadays invested in the brand naming process, assisted by computer programs, as well as psychological, linguistic and marketing experts.

7 Due to their similarity to proper names, commercial names tend to be capitalized, and thus constitute a separate morphological category [Baldi \& Dalwar 2000: 966]. If they become popular and well-accepted, brand names can make a transition into the cultural lexicon and sometimes even change their syntactic category (e.g. Hoover, $\mathrm{n} \rightarrow$ to hoover, $\mathrm{v}$; Xerox, $\mathrm{n} \rightarrow$ to xerox, $\mathrm{v})$. In other words, they contribute to the continuing expansion of the word stock. This process is, essentially, related to the syntactic role played by brand names - as a rule, they function as proper modifiers of common nouns or noun phrases [Stvan 2006:218], e.g. Nutter Butter cereal or Moosh dog shampoo. Incorrect practice leads to brand names being used without the accompanying noun (phrase), so they can ultimately end up as cover terms for a whole class of products.

When it comes to legal protectability, branding consultants commonly draw a distinction between four categories of names. In order of decreasing distinctiveness, these are: (a) fanciful or invented, (b) arbitrary, (c) suggestive, and (d) descriptive names [Blackett 1998: 10; Piller 2001: 194]. Fanciful names, such as Kodak or Pogo, are created ex nihilo and they represent the strongest, but also the least frequent type of trademark, due to their inherent distinctiveness. Arbitrary names are common words whose meaning is unrelated to their use as a trademark, e.g. Virgin as a record shop name or Orange in its use as a mobile network operator. Suggestive or imaginative names indirectly describe the product or service or refer to their attributes. Imagination is required for the inference of a connection between the name and the nature of the product or service concerned, e.g. Coppertone (suntan lotion) or Dove (soap). Descriptive names, as the term implies, describe the characteristics of the goods or services, for example Stick Fast or CarbMaster. According to Danesi [2008: 61-65], blends can be considered descriptive or suggestive names because some combinations of words describe the product make-up (e.g. Frogurt < frozen + yogurt) while others contain parts suggestive of a particular concept (e.g. Snack-tastic).

9 The formation of brand names operates under strict legal and marketing constraints. A newly introduced product or service in the US has to bear a distinctive name so it could enjoy legal protection. An oft-cited example of trademark infringement that resulted in the product name being changed is that of the Cheerios cereal, originally known as Cheerioats. Strategically desirable brand name characteristics include, besides distinctiveness, memorability, prononounceability, positive connotations, 
suggestiveness, and euphony [Robertson 1989; Stockwell \& Minkova 2001]. Although it might seem that originality plays a crucial role in the creation of a successful brand name, two opposing tendencies govern the process. In accordance with Bareš's views [1974: 183], Baldi and Dawar [2000: 966-967] explain that:

[O]n the one hand because of the need for products and services to stand out in the market, there is a call for new eye-catching patterns. On the other, convergence or analogy operates in support of an effort at uniformity, since consumers must recognize the word. This is why many brand names are coined following the same pattern.

For instance, many brand names contain the pseudo-scientific suffix -ex, such as Kleenex, Spandex or Durex, which exudes an air of science and scholarship due to its Latin origin. It was especially popular in the 1920s [Room 1994: 197] but seems to be favored in pharmaceutical products around the world in this day and age too (e.g. Zglobex in Serbia, Placentex in Italy).

11 Along similar lines, it is worth mentioning that the English lexicon has been expanding by means of loanwords, shortenings, composites (i.e. derivatives and compounds), blends and shifts [Algeo 1980]. The formation of trade names, which is not unlike the formation of common nouns, can be observed in accordance with the aforementioned taxonomy. French words, such as Beau or Bel(le), are used for their stylish associations [Room 1994:5]. Cafeteria, a loanword of Mexican Spanish origin, has provided a morphological pattern copied by many business enterprises, e.g. washateria, booketeria, spaghetteria [Pyles 1952: 202]. Shortening and blending, often described as the quintessential vehicles for linguistic creativity that fall under the scope of extragrammatical morphology because they fail to conform to the regular rules and models of word creation [Fandrych 2008; Ronneberger-Sibold 2010; Mattiello 2013), produce attention-grabbing names, such as Crunchy Loggs (< Kellogg's), Fanta (< fantasy/ fantastic), Pee-Ka-Poo (< peekaboo + poo) or Volumaniac (< volume + maniac). In general language, compounds are likely to contain two elements; in brand names, recursivity is frequently exploited with the aim of differentiating a particular product on the market through detailed description (e.g. Oven roasted chicken breast strip, Hungarian Thermal Water Mineral-Rich Atomic Heat Mask) or introducing a new variety of a well-known brand (e.g. Cocoa Puffs Ice Cream Scoop, Hubba Bubba Bubble Tape Mystery Flavor). Semantic shift, based on metaphorical and metonymic meanings, has contributed to the creation of many a brand name related to automobiles, such as Barracuda or Hot Wheels [Piller 1995].

12 Another interesting aspect of commercial names is word play. As an essential component of the language of advertising, the deliberate exploitation of phonological or graphological similarity of words aims to grab attention, entertain, convey meanings in an economical way and individualize a product amidst a host of other similar ones [Pennarola 2003: 22; Sjöblom 2016: 462]. Such an imaginative fusion of lexical items in blends as brand names, that draws on the richness and resourcefulness of the English spelling system, poses a pleasant intellectual riddle before the target audience, e.g. VitalEyes is a play on vitalize, Seeduction on seduction. For this reason, they might experience joy upon resolving the intended meaning of the pun [Djafarova 2008: 272]. 


\section{Blending and brand naming: Theory and research} creative nature has been observed in the works of William Shakespeare, Charles Dickens and Lewis Carroll, inter alia. In the distant past, blends or 'portmanteaus' were mostly formed as puns or terms of mockery [Adams 1973:149]. Their popularity increased considerably in the $20^{\text {th }}$ century due to the growing influence of the mass media and advertising. This has led to many a linguistic discussion of their structure, meaning and function but also many a disagreement vis-à-vis their definition and position within the morphological framework [Marchand 1969; Bauer 1983; Algeo 1991; Plag 2003]. As Bauer [1983:26] notes, delimiting blends from other morphological phenomena is no easy task because "blending tends to shade off into compounding, neo-classical compounding, affixation, clipping, and [...] acronyming". to focus on the characteristics of blends in brand names in Thurner's [1993] dictionary, his views on the topic will now briefly be discussed. In the introductory part of the book, the author [Thurner: vii] quotes a dictionary entry for blend from Webster's Third New International Dictionary, which could be taken as a defining criterion in his corpus gathering:

A word composed of parts of two words, all of one word and part of another, or two entire words, characterized invariably in the latter case and frequently in the two former cases by the single occurrence of one or more sounds or letters that appear in both the component words.

He states that portmanteaus can be distinguished from other types of compound words on account of their blending together shared characteristics of the source words. Also, Thurner believes that blends commonly merge the initial sounds or syllables of one word with the last of another (e.g. guesstimate), can merge like-sounding words for punning effect (e.g. sham-pagne) or even incorporate an entire word within another (e.g. metrollopis). As regards their growing popularity, he maintains that the pace of social and technological change accelerated dramatically at the turn of the century, rendering the traditional method of coining new words from roots of Greek or Latin provenance insufficient. Reliance on native language material enabled the formation of new words that could easily be introduced, understood and accepted in everyday use. Thurner's collection of blends shows that the major sources of new words, including the fields of aerospace and military technology, animal and plant hybridization, metallurgy, the advertising industry, the television and music industries, rock music and drug culture, all resort to blending.

As we have already mentioned, the importance of blending in product naming was recognized over a hundred years ago [Pound 1914]. It seems to have gained momentum in the 1950s, with the rise of new inventions, processes and experiences [Bryant 1974: 163]. Linguists [Leech 1966; Marchand 1969; Adams 1973; Algeo 1980] commented on the prevailing tendency of blends to appear in newspapers, magazines and TV commercials, that is the world of advertising. As Adams [1973:159] explained, "since they break the rules of morphology, blends have an attention-catching quality which makes them appropriate for trade names and other words in advertising copy". ${ }^{1}$ Advertisements were, therefore, primarily used for the collection of examples relating 
to brand names or trademarks, and their subsequent linguistic analyses. In the next few paragraphs we will examine the few relevant studies and discuss their findings.

There is a paucity of comprehensive research on product names in English. A notable exception is Praninskas's [1968] corpus-based book which sheds light on the structural characteristics of blends, albeit as haplological ${ }^{2}$ or clipped compounds. She discusses numerous instances of overlapping, that is, the use of one grapheme in place of two when the final sound of the first source word and the initial sound of the second source word in a compound may be represented by the same grapheme. This phenomenon, in her view an instance of phonemicization, encompasses both traditional and altered orthography (e.g. Airefiner, Hotray vs Quicold, Starkrimson) as well as graphemes with a bimorphemic reference (e.g. Flaxoap, Quixet). ${ }^{3}$ Moreover, she notes that the compounds in her corpus frequently contain hyphens which separate the two constituent free forms, either or both of which can be clipped (e.g. Aqua-Vac, Abdo-Fit). It is also worth noting that the author found examples of clippings as constituents of compounds being freed, i.e. occurring bounded on both sides by space, e.g. Musical Rama, Vani Chest. Today, we can confirm her intuition about the potential productivity of this pattern as it abounds on the market (e.g. Choco Donuts, Coco Pops, or Nutri Love, to name but a few brand names of children's cereal).

Bryant's [1974] corpus of 306 blends contains as many as 73 trade names (24\%) and many more product names that, at the time when the article was written, were not legally protected. The vast majority of them are semantically related to the fields of fashion, science and technology. It is worth mentioning that the orthographic conventions are not consistent. In addition to blends being written as single words, not infrequently a hyphen is used to mark the boundary between the source words (e.g. Tropic-nit < tropical + knit, Flare-trol < flare + control, Insta-lith < instant + lithography). Moreover, although bicapitalization has relatively recently been mentioned as a distinctive feature of Internet graphology [Crystal 2006: 93] or the high-tech sphere of language usage [Akmajian et al. 2010:36], it is quite noticeable in the corpus material, e.g. Lubri-Cushion, Perma-Gel, BritRail. Also, some blends contain parts of company names as initial or final elements, e.g. Excel-eze ( $<$ Excello + Celanese), Monro-Matic ( $<$ Monroe + automatic), Simflex ( $<$ Simmons + flexible), Kodacolor ( $<$ Kodak + color), Recordak ( $<$ record + Kodak). In line with the general propensity of the language of advertising to playfulness and unconventionality, several blends exhibit phonetically motivated nonstandard spellings (e.g. Dura-Wite, Securoslax < secure + o + slacks, Excel-eze, Polykor < polypropylene + kraftcord), make use of a phonetic realization of a particular morpheme or allomorph (e.g. Sudoprin < pseudo- + aspirin, Betarest < better + rest), contain non-English words (e.g. Cremogenized $<$ Fr. crème + homogenized) or unusual spellings (e.g. Feathaire, Escal-aire). Some of these trade names could nowadays be considered derivatives or compounds, because they contain full words, (a vowel) and what is often referred to as a combining form or a newly emerged affix, e.g.

Cruise-O-Matic, Ice-O-Matic: -matic, a combining form [McArthur 1996: 217] Perma-sized, Perma-crease: perma-, a possible derivational affix [Brinton 2000: 97]

Autostereo: auto-, a combining form [Saavedra 2014: 13]

Duraspeed: dura-, a combining form [McArthur 1996: 217]

AromaRama: -(o)rama, a combining form [Mattiello 2017: 70]. 
Bearing in mind the versatility of structural patterns observed in blends as brand names, the question which imposes itself is: how commercially successful are these blends? Cannon [2000:954] thinks that the most successful ones are those that are morphologically transparent:

For example, asphalt is a usual paving material, which, when considerably constituted of glass as the material, provides the commercial material glasphalt. Its meaning is a somewhat predictable combination of the meanings of its etyma, and is morphologically clearer than those of typical Renaissance English blends like flush $(<$ flash + gush), perhaps necessarily because people wish to know the contents of materials that they buy, as in beefish $(<$ beef + fish). The success of a trademark may depend on such predictability [...].

The aforementioned examples support the view that both phonological and graphological motivation contribute to the transparency of blends. When parts of the source words share phonemes or graphemes, it is easier to associate a blend with the source words and identify its meaning [Fischer 1998; Lehrer 2007]. For this reason, we can assume that haplology plays an important role in brand naming. This hypothesis will be tested on a corpus of approximately 600 brand names and trademarks gathered in the 1990s [Thurner 1993]. The results obtained could set the stage for explorations of more recently coined trade name blends.

\section{Blends in brand names: Findings and discussion}

\subsection{The corpus material}

The manually gathered corpus comprises 602 blends in brand names and trademarks listed in the Portmanteau Dictionary [Thurner 1993]. To our knowledge, this is the only reference book available that offers an abundance of examples pertaining to blending as a brand naming process. Admittedly, many of these blends are no longer in everyday use because their referents have vanished from the market over the course of time.

We purposely included all items labeled as brand names or trademarks in the corpus material so we could draw valid conclusions regarding their prototypical features. Blend words in the dictionary are accompanied by a brief description of the product or service, and the name of the manufacturer or parent company, e.g.

Theraffin brand name Paraffin wax for use in therapy, W.R. Medical Electronics Co.

which enabled us to draw conclusions about the origin of blends, their structure and meaning. In relation to this, we must admit that the identification of source words was not always a straightforward task (e.g. Bitinis, Lathurn). When in doubt, we compared our interpretations with Lavrova's [2016] or searched for the products on the Internet. Printed advertisements in newspapers or magazines, which can easily be found in online archives, provided valuable assistance.

The items excerpted were carefully examined in terms of their graphological, phonological, stylistic and semantic properties. To obtain numerical data, we performed a statistical analysis in the SPSS program, version 18.0. The results will be summarized in the following subsections. 


\subsection{Structural aspects of blends}

As anticipated, the blends in our corpus feature, to a striking degree (94\%), a phonological and/or graphological overlap. Taking into consideration the fact that some linguists claim that there is no overlap between the source words in most blends [Bauer 2003; Enarsson 2006], this finding indicates that blends in the language of advertising differ in certain aspects, structural complexity included, from those in general language.

Table 1: Frequency of blends based on the phonological/graphological similarity of the source words

\begin{tabular}{|l|l|}
\hline Type of blend & Number of blends in the corpus \\
\hline Overlapping & 565 \\
\hline Non-overlapping & 37 \\
\hline Total & 602 \\
\hline
\end{tabular}

A closer look at the data reveals that the vast majority of blends emerged as a result of the merging of two source words that overlapped both phonologically and graphologically. The extent of the overlap ranged from a single constituent to strings larger than a syllable, e.g. Weedigger ( $<$ weed + digger), Carpentree (< carpentry $+\underline{\text { tree }})$, Organimals ( $<$ organic + animals), Thunderwear $(<$ th $\underline{\text { under }}+$ underwear), Fictionary (fiction + dictionary). Less frequently, the constituents overlapped phonologically but not orthographically or vice versa, e.g. Beenut butter (< bee + peanut), Bisquick (< biscuit + quick), Campoo (< carpet + shampoo), Gloppets (< gl ove + puppets), Intellivison (intelligent $+\underline{\text { television}), ~ T o f o o d l e s ~(~}<$ tof $\underline{u}+$ noodles), Pleascent $(<$ pleasant $+\underline{\text { scent}})$, Plastinamel (< plastic + enamel), Pantimonium (pantyhose + pandemonium), Seaquarius (< sea + aquarius). Our results thus confirm Praninskas's [1968] observations. More importantly, they show that the dominant pattern concerns the overlap of full words (i.e. 'telescope blends'), that is, the merging of the hind part of the first source word with the fore part of the second source word (Table 2). Following Fandrych [2008], the various overlapping patterns can be classified into the following categories in order of decreasing frequency:

Table 2: Structural patterns and their frequency in overlapping blends

\begin{tabular}{|l|l|l|}
\hline Type of blend & Example & $\begin{array}{l}\text { Number of blends in the } \\
\text { corpus }\end{array}$ \\
\hline overlap of full words & Shampooch, Winterlude & 309 \\
\hline initial splinter + full word with overlap & Monstickers, Kaleidiskettes & 130 \\
\hline full word + final splinter with overlap & Deskretary, Legtronics & 77 \\
\hline initial + final splinter with overlap & Choclair, Immencils & 42 \\
\hline
\end{tabular}




\begin{tabular}{|l|l|l|}
\hline $\begin{array}{l}\text { insertion of one word into the other, with } \\
\text { overlap }\end{array}$ & $\begin{array}{l}\text { Abracurldabra, } \\
\text { Comfitables }\end{array}$ & 1 \\
\hline full word + initial splinter with overlap & Creamedic & 1 \\
\hline two splinters + full word with overlap & Cosmedicake & \\
\hline
\end{tabular}
overlapping blends, some more frequent than others. Although blends are often defined as generally consisting of an initial splinter of the first source word and the final splinter of the second source word [e.g. Brinton 2000; Plag 2003; Miller 2014], our results suggest that this is not the case with commercial blends. The commonest pattern combines an initial splinter followed by a full word, e.g. Apricoating ( $<$ apricot + coating), Calendial (< calendar + dial), Shampure (< shampoo + pure), Qualitone (< quality + tone), Umbrellegant (< umbrella + elegant). Half as common were instances of a full word being fused with a final splinter, e.g. Carpetriever ( $<$ carpet + retriever), Bassitar ( $<$ bass + guitar), Dogloo ( $<$ dog + igloo), Gingeraffe (< ginger + giraffe), Gymboree (< gym + jamboree), Manwich (< man + sandwich), Petzels (< pet + pretzels), Rockoustics (< rock + acoustics), Superamics ( $<$ super + ceramics), Yardener ( $<$ yard + gardener). In some blends the phonemes of both source words are fully preserved but there is a loss of graphemes, e.g. Homade (< home + made), Locktagons ( < lock + octagons), Neverinkle (< never + wrinkle), Sensurround ( $<$ sense + surround), Quiclip (quick + clip). The aforementioned prototypical pattern (i.e. initial splinter + final splinter) occurred much more rarely, e.g. Alaskimo (< Alaska + Eskimo), Crantastic (< cranberry + fantastic), Cosmerica (< cosmetic + America), Executary ( $<$ executive + secretary), Leasuramics (< leasure + ceramics), Mexicatessen $(<$ Mexican + delicatessen), Pleasoning $(<$ pleasant + seasoning), Tofait ( $<$ tofu + parfait), Scrunge ( $<$ scrub + spunge), Umbroller ( $<$ umbrella + stroller). The combinations of a full word and an initial splinter were practically nonexistent whereas other possibilities, such as the fusion of a final splinter and an initial splinter, two initial splinters or two final splinters remained unexploited [Fandrych 2008; Mattiello 2013]. Intercalative blends, with words being inserted within a discontinuous splinter, also occurred quite rarely, e.g. Abracurldabra ( $<$ abracadabra + curl), Comfitables (< comfortables + fit), Erusticator (< eradicator + rust), Glorifried $(<$ glorified + fry), Irrezeastables ( $<$ irresistables + freeze). Finally, we recorded a single blend consisting of two splinters and a full word, Cosmedicake ( $<$ cosmetic + medical + cake). 
Table 3: Structural patterns and their frequency in non-overlapping blends

\begin{tabular}{|l|l|l|}
\hline Type of blend & Example & Number of blends in the corpus \\
\hline full word + final splinter & Soygurt, Eggcessories & 18 \\
\hline initial splinter + full word & Liquifry, Identikit & 11 \\
\hline initial splinter + final splinter & Chudge, Yogonnaise & 7 \\
\hline full word + thematic vowel + final splinter & Herbacue & 1 \\
\hline
\end{tabular}

Evidently, in non-overlapping blends the most common pattern involved the fusion of a full word and a final splinter, e.g. Defendamins (< defend + vitamins), Eggspendables (< egg + expendables), Funbrella ( $<$ fun + umbrella), Jagwire ( $<$ Jaguar + wire), Rooflex ( $<$ roof + complex). Less frequent were the combinations of an initial splinter and a full word, e.g. Electrocities (< electronic + cities), Extenzyme (< extensive + enzyme), Lathurn (< lathering + urn), Lubath (< luxury/luxurious + bath), Penetroil (< penetrating + oil), Smorgasgrill (< smorgasboard + grill). The same goes for the merging of an initial and a final splinter, e.g. Instamatic ( $<$ instant + automatic), Porschpoiler (< Porsche + spoiler). We also noted a single occurrence of a full word followed by a thematic vowel $-a-$ and a final splinter (Herbacue $<$ herb $+\mathrm{a}+$ barbecue).

31 Compared with other relevant data sets pertaining to blends in trade names, our results demonstrate that the overlap of full words has gained popularity as a trade naming mechanism. On the other hand, hyphenated blends that were quite common in Praninskas's [1968] and Bryant's [1974] studies are literally absent from the corpus material. It stands to reason that in mid- $20^{\text {th }}$ century, when the use of hyphens and thematic vowels in compound brand names was popular, blends too were often hyphenated. With blending becoming increasingly more common as a trade naming device, the use of the hyphen might have decreased. Another, more plausible, explanation for their absence in the corpus might be of a methodological nature. Thurner [1993] did not explicitly mention hyphenated blends in the introductory part of his book so it is possible that he considered them compounds, not blends and, consequently, decided against incorporating them into the corpus material.

The use of company names in brand names and trademarks, which is nowadays perhaps most easily noticeable in Nestlé's range of products (e.g. Nescafé, Nesquik, Nespresso, Nespray, Nestea, Nestomalt, Nesplus, Nestum, Nesvita), serves as a mark of their identity, quality and good will. Historically speaking, it can be traced back to the 1930s when Berrey [1939] made a record of Shellubrication. Considering that Bryant's corpus [1974] also includes a few examples of this sort (e.g. Kodacolor, Simflex), we expected a number of similar creations to appear in our selection of trade names. However, given the size of the corpus, their number is relatively small, e.g. Angelicare (< Angelica + care), Angelicreation ( $<$ Angelica + creation), Atlashield ( $<$ Atlas + shield), Canoah ( $<$ canoe + Noah), Charmaid ( $<$ Charma + aid), Charmaternity ( $<$ Charma + maternity), Charmour ( $<$ Charma + armour), Pandorable (< Pandora + adorable), Pulstar (< Pulse + star), Timinder (< Timark + reminder). Interestingly, in almost all of these blends the company name appears in its (clipped) form in the sinistral position (the only exception being Canoah). This is possibly related to the assumption that "the beginning letters in a word are 
more important to process than the middle or ending letters" [Kucer 2014:116]. A company wishing to capitalize on the existing image and reputation could therefore strategically first draw attention to its name when introducing new products or services. With every new reproduction, the company name becomes more and more easily recognizable on the market.

\subsection{Stylistic aspects of blends} and literature to politics and government, from business and finance to science and technology. Blends in trade names have not been subjected to similar classifications and quantifications. We only have rudimentary knowledge of the popularity of blending as a naming device of food items [Danilović Jeremić \& Josijević forth.; Danilović Jeremić \& Josijević 2019] and pharmaceutical products [Ungerer 1991: 143]. Taking this into account, we attempted to categorize our data (Table 4) in line with the International trademark classes of goods and services [Rivkin \& Sutherland 2004: 225] 
which can be regarded as a more detailed list of semantic fields mentioned in the relevant literature on blends [Bryant 1974; Cannon 1986]. ${ }^{5}$

Table 4: Most frequently occurring (semantic) classes of blends

\begin{tabular}{|l|l|l|}
\hline Class & Example & $\begin{array}{l}\text { Number of blends } \\
\text { in the corpus }\end{array}$ \\
\hline $\begin{array}{l}\text { meats and processed foods, staple foods, natural } \\
\text { agricultural products, light beverages, wines and } \\
\text { spirits }\end{array}$ & Giantarts, Flavorama & 68 \\
\hline electrical and scientific apparatus & $\begin{array}{l}\text { Communicenter, } \\
\text { Insectocutor }\end{array}$ & 65 \\
\hline toys and sporting goods & Crawligator, Lightarget & 56 \\
\hline paper goods and printed matter & Clipad, Grinvitations & 50 \\
\hline cosmetics and cleaning preparations & Fabulash, Organicolor & 49 \\
\hline houseware and glass & Guestray, Mercandescent & 47 \\
\hline clothing & Califamous, Footrue & 38 \\
\hline
\end{tabular}

Our analysis shows that blends occur frequently in the names of products that play an important role in our everyday lives: foods and beverages, electronic gadgets and devices, toys and sporting equipment, stationery, cosmetics, houseware and clothes (including footwear). These groupings accommodate $62 \%$ of all items. Other classes worth mentioning are metal goods ( 28 blends), furniture ( 28 blends), pharmaceuticals (26 blends) and paints (23 blends). This is (partially) in line with Bryant's [1974] results as she, too, mentions fashion, home, sports and entertainment as well as science and technology as the most productive semantic fields. On the other hand, we found few examples of blends in the names of lubricants and fuels ( 2 blends), floor coverings ( 3 blends), musical instruments ( 8 blends) and non-metallic building materials ( 7 blends) while some classes of goods, such as firearms or yarns and threads, contained virtually no blends.

Obviously, certain classes of goods exploit blending as a naming strategy more often than others. The rapid rate of new product introductions might be forcing the companies of goods that are in high demand to exploit word coinages in an effort to catch attention and maintain their competitive position on the market [Weston \& Chiu 1996]. Also, blends offer a unique possibility of merging two meanings so "they are likely to be names of 'mixtures' or hybrids" [Adams 1973: 158]. Eleven blends in the corpus support this claim (e.g. Accortina < accordion + concertina; Calculighter < calculator + cigarette lighter; Carboloy < carbon + alloy; Cemestos < cement + asbestos; Clamato < clam + tomato; Combrush < comb + brush; Koalaby < koala + wallaby; Raisinuts < raisin + nuts; Spoodle < spoon + ladle; Supremium < supreme + premium; Woolyester < wool + polyester). Although some companies might simply have been following trends in naming practices, we believe socio-economic aspects have been instrumental in 
popularizing blending in brand names and trademarks. The food industry has been expanding and diversifying over the years, bringing new flavors, variants (e.g. precooked, sugar-free, low-fat) or combinations of foods and beverages onto the market (e.g. Cinnamint < cinnamon + mint; Pumpernibbles < pumpernickel + nibbles; Vitamilk < vitamin + milk) because "consumers demand variety" [Weston \& Chiu 1996: 22].6 Moreover, technological developments have revolutionized our way of living and working, making us dependent on a vast array of once unimaginable electronic devices and equipment (e.g. Casseiver < cassette + receiver; Fathometer < fathom + meter; Identikit < identity + kit). With more discretionary income came more possibilities for leisure and recreation time [Lazer 1994], such as numerous games, toys and sporting goods (e.g. Yardarts < yard + darts; Mechanimals < mechanic + animals; Spinsect < spinning + insect). Office supplies have increased in number and variety too, offering tools that help us manage and organize work more efficiently (e.g. Calmanac < calendar + almanac; Magicrayon < magic + crayon; Superase < super + erase). ${ }^{7}$ So have cosmetic products which are continuously evolving, testing ingredients and launching trends in hair styles or make up (e.g. Delicare < delicate + care; Hairobics < hair + aerobics; Instantan < instant $+\tan )$. The wealth of new products in all of the aforementioned classes needed attractive, memorable and evocative names. Blending met all of these needs in a distinctive way, offering the seldom exploited possibility of merging full words to trade name creators. Apart from serving as attention-grabbers, we maintain that blends in commercial names, as newly coined words, reflected the novelty and modernity of their referents. ${ }^{8}$

\section{Conclusion}

Brand names are fascinating linguistic phenomena. Carefully crafted, they represent the initial step in establishing communication between companies and consumers whenever a new product or service is being launched. From a sociological standpoint, they reflect our needs, lifestyles and attitudes, shaped by the ever-changing landscape of technological advances. From a linguistic standpoint, they mirror language development: depending on the times and trends, certain patterns flourish because an innovative formation is gaining popularity (e.g. names ending in $-e x,-o$ or $-a$; see Room [1994]).

41 The results of our analyses suggest that haplology plays a vital role in the creation of blends in brand names. While this is not surprising, given that similar observations regarding its function in the identification of source words have been put forward by other researchers [e.g. Fischer 1998; Cannon 2000; Lehrer 2007], we did not expect to find such an impressive number of blends involving the overlap of full words. These findings indicate that a very popular way of forming blends in the 1990s included a seamless fusion of two source words which rendered them semantically fully transparent, at least when seen in print. We can therefore conclude that visual motivation was very strong at the time - blends were to be seen as labels on the packaging or in advertising material. Also noteworthy is their playful character as a number of blends in our corpus are based on close similarity between source words or their fragments. Last but not least, as opposed to Ungerer's [1991] point of view, we have shown that blends are systematically used not only in the names of 
pharmaceutical products, but across a whole range of goods which form an essential part of our everyday lives.

Almost sixty years ago, Lippincott and Margulies (cited in Praninskas [1968:11]) commented on "a mounting crisis in marketing - the problem of finding new names for new products". Nowadays, with well over a million and a half active trademark registrations in the US [Johnson 2012], the situation seems to be even more challenging. Beebe and Fromer [2018] have recently put forward an empirical claim that the supply of effective trademarks is not inexhaustible because $62 \%$ of the 10,000 most frequently used words in American English have already been claimed as single word-marks. Accordingly, we can expect marketing and advertising experts to search for new naming strategies, possibly increasing the number of blends in brand names and trademarks. With our lifestyles and living conditions changing by the day, new issues are emerging (e.g. time poverty, obesity, global warming) and new commercial possibilities are arising. Some structural patterns in newly formed blends will probably become productive, leading to the emergence of new splinters and potential affixes. Furthermore, combinations of three (or more) source words, so far rather rare, could be expected to grow in number. Finally, with the rise of international markets and online trade opportunities, company names could proliferate in blends to benefit from their well-established reputation (as appears to be the case in Romanian advertising [Popescu 2015]). Further explorations of brand names and trademarks should test these hypotheses and enrich our existing body of knowledge on the dynamics of brand name change.

\section{BIBLIOGRAPHY}

ADAMS Valerie, 1973, An Introduction to Modern English Word-Formation, Harlow: Longman.

AKMAJIAN Adrian et al., 2010 [1980], Linguistics: An Introduction to Language and Communication, Cambridge, Massachusetts: MIT Press.

ALGEO John, 1980, “Where do all the new words come from?”, American Speech, Vol. 55, N, 264-277.

ALGEO John (Ed.), 1991, Fifty Years Among the New Words: A Dictionary of Neologisms, Cambridge: Cambridge University Press.

BALDI Philip \& DAWAR Chantal, 2000, “Creative processes”, in BOOIJ Geert (Ed.), Morphology: An International Handbook on Inflection and Word-Formation Vol. 1, Berlin/New York: de Gruyter, 963-972.

BAREŠ Karel, 1974, “Unconventional word-forming patterns in present-day English”, Philologica Pragensia, Vol. 17, 173-186.

BAUER Laurie, 1983, English Word-formation, Cambridge: Cambridge University Press.

BAUER Laurie, 2003 [1988], Introducing Linguistic Morphology, Cambridge: Cambridge University Press. 
BAUER Laurie, LIEBER Rochelle \& PLAG Ingo, 2013, Oxford Reference Guide to English Morphology, Oxford: Oxford University Press.

BEEBE Barton \& FROMER Jeanne, 2018, “Are We Running out of Trademarks? An Empirical Study of Trademark Depletion and Congestion", Harvard Law Review, Vol. 131, №4, 948-1043.

BERREY Lester, 1939, “Newly-wedded words”, American Speech, Vol. 14, N¹, 3-10.

BLACKETT Tom, 1998, Trademarks, London: MacMillan Press LTD.

BÖHMEROVÁ Ada, 2010, Blending as Lexical Amalgamation and Its Onomatological and Lexicographical Status in English and in Slovak, Bratislava: ŠEVT.

BRINTON Laurel, 2000, The Structure of Modern English: A Linguistic Introduction, Amsterdam/ Philadelphia: John Benjamins.

BRYANT Margaret, 1974, "Blends are increasing”, American Speech, Vol. 49, N³-4, 163-184.

CANNON Garland, 1986, "Blends in English word formation", Linguistics, Vol. 24, 725-753.

CANNON Garland, 2000, "Blending", in BOoIJ Geert (ed.), Morphology: An International Handbook on Inflection and Word-Formation Vol. 1, Berlin/New York: de Gruyter, 952-956.

COOK Vivian, 2005 [2004], Accomodating Brocolli in the Cemetary, New York: Touchstone.

CRYSTAL David, 2006 [2001], Language and the Internet, Cambridge: Cambridge University Press.

DANESI Marcel, 2008, Why It Sells: Decoding the Meanings of Brand Names, Logos, Ads, and Other Marketing and Advertising Ploys, Lanham: Rowman \& Littlefield Publishers, Inc.

DANILOVIĆ JEREMIĆ Jelena \& JOSIJEVIĆ Jelena, forthcoming, “Creative morphology in brand names of baby products: An analysis of compounds and blends".

DANILOVIĆ JEREMIĆ Jelena \& JOSIJEVIĆ Jelena, 2019, “A cerealicious brekki: A linguistic analysis of children's cereal boxes", Paper presented at the international conference BELLS 90, May 30-June 1, Belgrade: Faculty of Philology.

DJAFARova Elmira, 2008, "Why Do Advertisers Use Puns? A Linguistic Perspective”, Journal of Advertising Research, Vol. 48, N² 267-275.

ENARSSON Anna, 2006, New Blends in the English Language, Karlstad: Karlstad Universitet.

FANDRYCH Ingrid, 2008, "Submorphemic elements in the formation of acronyms, blends and clippings”, Lexis, Vol. 2, 103-121.

FISCHER Roswitha, 1998, Lexical Change in Present-Day English: A Corpus-Based Study of the Motivation, Institutionalization, and Productivity of Creative Neologisms, Tübingen: Gunter Narr Verlag.

GITLIN Martin \& ELLIS Topher, 2011, The Great American Cereal Book: How Breakfast Got Its Crunch, New York: Abrams Image.

HLADKY Josef, 1971, "The orthography of British trade names", Sbornik prací filozofické fakulty brněnské university, A19, 145-160.

JOHNSON Christopher, 2012, Microstyle: The art of writing little, London/New York: W. W. Norton \& Company.

KUCER Stephen, 2014, A Conceptual Base for Teaching Reading and Writing in School Settings, New York/ Abingdon: Routledge. 
LAVROVA Natalie, 2016 [2009], АНГЛО-РУССКИЙ СЛОВАРЬ СОВРЕМЕННЫЕ ТЕНДЕНЦИИ В СЛОВООБРАЗОВАНИИ: КОНТАМИНАНТЫ, МОСКВА: ФЛИНТА.

LAZER William, 1994 [1987], Handbook of Demographics for Marketing and Advertising: New Trends in the American Marketplace, New York: Lexington Books.

LEECH Geoffrey, 1966, English in Advertising: A Linguistic Study of Advertising in Great Britain, London: Longmans.

LEHRER Adrienne, 2003, “Understanding trendy neologisms”, Rivista di Linguistica, Vol. 15, №2, 371-384.

LEHRER Adrienne, 2007, “Blendalicious”, in MUNAT Judith (Ed.), Lexical Creativity: Texts and Contexts, Amsterdam/Philadelphia: John Benjamins, 115-133.

LIEBER Rochelle, 2009, Introducing Morphology, Cambridge: Cambridge University Press.

LIPPINCOTT Gordon \& MARGULIES Walter, 1961, "How to name a product", Management methods, Vol. 2, 47-51.

MARCHAND Hans, 1969 [1960], The Categories and Types of Present-Day English Word-Formation: A Synchronic-Diachronic Approach, München: Verlag C.H. Beck.

MATTIELLo Elisa, 2013, Extra-grammatical morphology in English: Abbreviations, Blends, Reduplicatives, and Related Phenomena, Berlin/Boston: Walter de Gruyter.

MATTIELlo Elisa, 2017, Analogy in Word-formation: A Study of English Neologisms and Occasionalisms, Berlin/Boston: Walter de Gruyter.

MCARTHUR Tom, 1996, The Concise Oxford Companion to the English Language, Oxford: Oxford University Press.

MILLER Gary, 2014, English Lexicogenesis, Oxford: Oxford University Press.

PANIĆ Olga, 2004, "Brand names: How they are made and what they are made for", British and American Studies Journal, Vol. 10, 285-291.

PENNAROLA Cristina, 2003, Nonsense in advertising: Deviascion in English Print Ads, Napoli: Liguori Editore.

PILLER Ingrid, 1995, American Automobile Names, PhD thesis, Dresden: Technische Universität, also available at http://www.languageonthemove.com/wp-content/uploads/2011/02/ piller_1995_american-automobile-names.pdf PILLER Ingrid, 1999, “Iconicity in brand names”, in NANNY Max \& FISCHER Olga (Eds.), Form miming meaning: Iconicity in language and literature, Amsterdam: John Benjamins, 325-341.

PILLER Ingrid, 2001, “Brand Name Formation”, Nomina Africana, Vol. 15, Nº1-2, 189-202.

PILLER Ingrid, 2005, “Naming”, in STRAZNY Philip (Ed.), Encyclopedia of Linguistics, New York: Fitzroy Dearborn, 724-726.

POUND Louise, 1914, Blends: Their Relation to English Word Formation, Heidelberg: Carl Winter's Universitätsbuchhandlung.

PLAG Ingo, 2003, Word-formation in English, Cambridge: Cambridge University Press.

POPESCU Alina Raluca, 2015, "On the portmanteau words based on commercial names in current Romanian advertising", Diversité et Identité Culturelle en Europe, Vol. 12, №2, 215-232.

PRANINSKAS Jean, 1968, Trade name creation: Processes and patterns, The Hague: Mouton. 
PYLES Thomas, 1952, Words and Ways of American English, New York: Random House.

RIVKIN Steve \& SUTHERLAND Fraser, 2004, The making of a name: The inside story of the brands we buy, New York: Oxford University Press.

ROBERTSON Kim, 1989, "Strategically desirable brand name characteristics", The Journal of Consumer Marketing, Vol. 6, No. 4, 61-71.

RooM Adrian, 1994 [1991], NTC's Dictionary of Trade Name Origins, Lincolnwood: NITC Business Books.

RONNEBERGER-SIBOLD Elke, 2010, "Word creation: Definition - Function - Typology", in RAINER Franz et al. (Eds.), Variation and Change in Morphology: Selected Papers from the $13^{\text {th }}$ International Morphology Meeting, Vienna, February 2008, Amsterdam: John Benjamins, 201-216.

THURNER Dick, 1993, Portmanteau Dictionary: Blend Words in the English Language, Including Trademarks and Brand Names, Jefferson: McFarland \& Company, Inc.

SAAVEDRA CORREIA David, 2014, “Automatically identifying blend splinters that are morpheme candidates", Digital Scholarship in the Humanities, Vol. 31, N $1,55-71$.

SJÖвloм Paula, "Commercial Names", in Hough Carole (Ed.), The Oxford Handbook of Names and Naming, Oxford: Oxford Universiy Press, 453-464.

STOCKWELL Robert \& MINKOVA Donka, 2001, English Words: History and Structure, Cambridge: Cambridge University Press.

STVAN Laurel, 2006, “The contingent meaning of -ex brand names in English", Corpora, Vol. 1, $\mathrm{N}^{\circ} 2$, 217-250.

UNGERER Friedrich, 1991, “Acronyms, trade names and motivation”, AAA: Arbeiten aus Anglistik und Amerikanistik, Vol. 16, N², 131-158.

WESTON Fred \& CHIU Susan, 1996, "Growth Strategies in the Food Industry”, Business Economics, Vol. 31, N ${ }^{\circ}$, 21-27.

\section{NOTES}

1. The Learn to speak Snacklish ad campaign, which, for the most part, made use of lexical blends in the distinctive Snickers colors on a chocolate brown background, proves this point (e.g. snaxi, chewniversity, satisflying, chocollege, chewpiter, yumazing, social nutwork, chompensation, chompion, feedquipment, satisfectellent).

2. Adams [1973: 150] defines haplology as the overlapping of vowels, consonants or syllables, e.g. privilegentsia (< privilege + intelligentsia) or selectorate (< select + electorate).

3. We capitalized examples, originally presented in small caps, from Praninskas [1968] to achieve uniformity throughout the paper.

4. Interestingly, the only occurrence of the negative determiner in English blends was recorded in Magnox [Renner cited in Böhmerová 2010: 81].

5. Blends occurred in the names of few services (e.g. Bestemps, an employment service; Domesticare, a home-cleaning franchise; Frostop, a fast-food franchise; Travelodge, a hotel/motel chain) so we decided to exclude them from the results presented in this part of the paper.

6. According to recent estimates, the food manufacturing industry in the US generates a revenue of approximately $\$ 760$ billion per year (see https://www.cmtc.com/blog/food-and-beveragemanufacturing-trends-and-challenges-2016). 
7. For more information about the development of stationery stores see https:// www.referenceforbusiness.com/industries/Retail-Trade/Stationery-Stores.html

8. A more detailed semantic investigation focusing on the relationships between the constituents of the target blends falls outside the scope of this paper due to the size of the corpus.

\section{ABSTRACTS}

Brand names represent valuable linguistic assets. They serve a variety of purposes, from product differentiation to corporate identity. Creativity and wit are employed in brand naming practices, frequently resulting in the formation of blends. Although blending has long been recognized as a prominent feature of advertising and marketing discourse, next to no research has hitherto been devoted to blends in brand names. Hence, the aim of this paper is to analyze approximately 600 brand names excerpted from the Portmanteau Dictionary [Thurner 1993]. Having examined the phonological, graphological, stylistic and semantic motivations, we conclude that the distinguishing features of blends in brand names are the overlap of full words and word play. In terms of particular classes of goods, blends seem to permeate the names of foods and beverages, electrical and scientific devices, toys and sporting equipment, as well as stationery, cosmetics and houseware.

Les noms de marque représentent des atouts linguistiques indéniables et remplissent de multiples fonctions, de la différentiation du produit jusqu'à la création et/ou le renforcement de l'image de marque de la société. La créativité linguistique et les jeux de mots sont convoqués lors de la création d'un nom de marque, qui prend fréquemment la forme d'amalgames. Bien que le rôle du phénomène d'amalgamation ait été depuis longtemps reconnu comme une caractéristique dominante $\mathrm{du}$ discours publicitaire et du discours du marketing, quasiment aucune recherche n'a été consacrée jusqu'à présent au rôle des amalgames dans les noms de marque, d'où l'objectif de cet article, qui consiste à analyser les quelque 600 noms de marque trouvés dans le Portmanteau Dictionary [Thurner 1993]. Après avoir étudié les motivations phonologiques, graphiques, stylistiques et sémantiques, nous concluons que les traits distinctifs des amalgames dans les noms de marque résident dans le chevauchement de mots entiers et de jeux de mots. En ce qui concerne les types de produits concernés, il semble que les amalgames s'infiltrent aussi bien dans les noms de boissons et nourritures, d'appareils électriques et scientifiques, de jouets et de matériels sportifs que dans les noms de cosmétiques et d'articles ménagers.

\section{INDEX}

Mots-clés: amalgamation, noms de marques, marques déposées, corpus Thurner

Keywords: blending, brand names, trademarks, the Thurner corpus 
AUTHORS

JELENA DANILOVIĆ JEREMIĆ

University of Kragujevac

jelena.jeremic@filum.kg.ac.rs

JELENA JOSIJEVIĆ

University of Kragujevac

jelena.josijevic@filum.kg.ac.rs 